\title{
Study of the nickel-phosphorus coating structural-phase states
}

\author{
Igor Shcherbakov* \\ Don State Technical University, Rostov-on-Don, Russian Federation
}

\begin{abstract}
The results of modeling a composite nickel-phosphorus coating obtained by chemical deposition are presented. The state of structuralphase disordering of the coating surface is considered. The analysis of possible structural states in the surface layers of the coating is carried out. A graph of $\mathrm{Me}$ atoms volume changes in phosphorus-containing compounds $\mathrm{Me}_{\mathrm{x}} \mathrm{P}_{\mathrm{y}}(\mathrm{Me}-\mathrm{Fe}, \mathrm{Cr}, \mathrm{Ni})$ and the maximum stability temperature $\mathrm{Ni}_{\mathrm{x}} \mathrm{P}_{\mathrm{y}}$ is plotted depending on the composition. The idealized images of the projections of tetragonal and trigonal phosphorus-containing phases structures are constructed.
\end{abstract}

Nickel-phosphorus coating, obtained by chemical deposition on the steel surface, has a low degree of crystallinity and contains from 8 to $12 \%$ of phosphorus depending on the deposition modes. Subsequent surface heat treatment leads to the formation of crystalline phases Ni и Ni3P [1-8].

Under tribomechanical action on parts with a nickel-phosphorus coating applied to it, the phase composition in its surface layers can change due to possible mechanochemical reactions, diffusion processes, polymorphic and morphotropic transformations. Since the Ni - P system can form several more phosphorus-containing phases with a relatively low phosphorus content: $\mathrm{Ni}_{5} \mathrm{P}_{2}, \mathrm{Ni}_{12} \mathrm{P}_{5}, \mathrm{Ni}_{2} \mathrm{P}, \mathrm{Ni}_{5} \mathrm{P}_{4}$ [4-6], then the state of the surface layer can be characterized by a state of phase disordering.

In accordance with [7], we assume that along with phase disordering in the surface layers of the material, a state of structural-phase disordering is possible. - the phenomenon of the simultaneous existence of different composition phases, each of which is in several structural modifications. Tribomechanical effects on the surface of a nickel-phosphorus coating are accompanied by point deformations and a local increase in temperature up to $1000-1200^{\circ} \mathrm{C}$ [6] and can initiate the formation of phases with a developed network of interphase boundaries. The structures of possible phases derived from phosphorus-containing compounds in the $\mathrm{Ni}-\mathrm{P}$ system and characterized by the same or similar cells as the original compounds are obtained in accordance with the methodology [6-7]. The number of formula units in a unit cell is indicated in the tables next to the symbol of the phase space group. Structural data are used to analyze possible phase structures [6-7]. The description of the occupied lattice complexes characteristics, denoted below in accordance with [6], includes the symbol of the crystallographic position (Wyckoff multiplicity and designation) and its positional symmetry. It is necessary to pay

\footnotetext{
* Corresponding author: bdd-don@mail.ru
} 
attention to the obvious relatedness of the phase sets for $\mathrm{Ni}_{5} \mathrm{P}_{2}, \mathrm{Ni}_{2} \mathrm{P}$ и $\mathrm{Ni}_{5} \mathrm{P}_{4}$ (table 1, table 2), as well as for $\mathrm{Ni}_{3} \mathrm{P}$ and $\mathrm{Ni}_{12} \mathrm{P}_{5}$ (table 3).

Table 1. Characteristics of occupied positions in possible structures of phases corresponding to compounds $\mathrm{Ni}_{5} \mathrm{P}_{2}, \mathrm{Ni}_{5} \mathrm{P}_{4}$

\begin{tabular}{|c|c|c|c|}
\hline S.g. (z) & $\mathrm{Ni}_{5} \mathrm{P}_{2}$ & S.g. (z) & $\mathrm{Ni}_{5} \mathrm{P}_{4}$ \\
\hline P $\overline{6} 2 \mathrm{~m}(3)$ & - & $\mathrm{P}_{3} \mathrm{mc}(3)$ & $\begin{array}{l}\text { 20Ni: } 2(a) 3 m+6(c) m+12(d) 1 \\
\text { 16P: }(2(a)+2(b)) 3 m+2 * 6(c) m\end{array}$ \\
\hline P 6 (3) & - & $\mathrm{P}_{3}(4)$ & $\begin{array}{c}\text { 20Ni: } 2(\mathrm{a}) 3+3 * 6(\mathrm{c}) 1 \\
\text { 16P: }(2(\mathrm{a})+2(\mathrm{~b})) 3+2 * 6(\mathrm{c}) 1 \\
\end{array}$ \\
\hline P321 (3) & - & P3м1 (4) & $\begin{array}{c}\text { 20Ni: } 2 *(1(\mathrm{a}) 3 \mathrm{~m}+3(\mathrm{~d}) \mathrm{m}+6(\mathrm{c}) 1) \\
16 \mathrm{P}: 2 *(1(\mathrm{a})+1(\mathrm{~b})+1(\mathrm{c})) 3 \mathrm{~m}+4 * 3(\mathrm{~d}) \mathrm{m}\end{array}$ \\
\hline P31m (3) & - & P31c(4) & $\begin{array}{c}\text { 20Ni: } 2 *(2(a) 3+2(b) 3+6(d) 1) \\
16 \mathrm{P}:(2(a)+2(b)) 3+2 * 6(d) 1\end{array}$ \\
\hline Pmm2 (8) & - & $\mathrm{Cmc}_{1}(8)$ & $\begin{array}{c}\text { 40Ni: } 2 * 4(\mathrm{a}) \mathrm{m}+4 * 8(\mathrm{~b}) 1 \\
\text { 32P: } 4 * 4(\mathrm{a}) \mathrm{m}+2 * 8(\mathrm{~b}) 1 \\
\end{array}$ \\
\hline P3 (4) & $\begin{array}{l}20 \mathrm{Ni}: 2(\mathrm{a}) 3+6 * 3(\mathrm{~d}) 1 \\
8 \mathrm{P}: 1(\mathrm{~b}) 3+1(\mathrm{c}) 3+2 * 3(\mathrm{~d}) 1\end{array}$ & P3 (4) & $\begin{array}{l}20 \mathrm{Ni}: 2 * 1(\mathrm{a}) 3+6 * 3(\mathrm{~d}) 1 \\
16 \mathrm{P}:(2 * 1(\mathrm{a})+1(\mathrm{~b})+1(\mathrm{c})) 3+4 * 3(\mathrm{~d}) 1\end{array}$ \\
\hline $\mathrm{Bm}(8)$ & - & $\mathrm{Bm}(8)$ & $\begin{array}{c}\text { 40Ni: } 2 * 2(\mathrm{a}) \mathrm{m}+9 * 4(\mathrm{~b}) 1 \\
32 \mathrm{P}: 4 * 2(\mathrm{a}(\mathrm{m}+6 * 4(\mathrm{~b}) 1\end{array}$ \\
\hline
\end{tabular}

It should be noted the changes in the characteristics of occupied lattice complexes:

1)for the transition from the $\mathrm{Ni}_{5} \mathrm{P}_{2}$ structure to the $\mathrm{Ni}_{5} \mathrm{P}_{4}$ structure in the case of $\mathrm{P} 3$ - phases

(Ni: $2 * \mathrm{P}\{\mathrm{z}\}+6 * \mathrm{P} 3 \mathrm{xy}\{\mathrm{z}\} ; \mathrm{P}: 2 * \mathrm{P}\{\mathrm{z}\}+2 * \mathrm{P} 3 \mathrm{xy}\{\mathrm{z}\}) \Leftrightarrow$

(Ni: $2 * \mathrm{P}\{\mathrm{z}\}+6 * \mathrm{P} 3 \mathrm{xy}\{\mathrm{z}\} ; \mathrm{P}: 4 * \mathrm{P}\{\mathrm{z}\}+4 * \mathrm{P} 3 \mathrm{xy}\{\mathrm{z}\})$

2)for transitions from the $\mathrm{Ni}_{3} \mathrm{P}$ structure to the $\mathrm{Ni}_{12} \mathrm{P}_{5}$ structure in the case of the $\mathrm{I} \overline{4}-$ phases

$$
\text { (Ni: 3*I4xyz; P: I4xyz) } \Leftrightarrow \quad(\mathrm{Ni}: 3 * I 4 x y z ; \text { P: I + I4xyz) }
$$

and B2-phases

$$
\text { (Ni: 6*B2xy }\{\mathrm{z}\} ; \mathrm{P}: 2 * \mathrm{~B} 2 \mathrm{xy}\{\mathrm{z}\}) \Leftrightarrow\left(\mathrm{Ni}: 6^{*} \mathrm{~B} 2 \mathrm{xy}\{\mathrm{z}\} ; \mathrm{P}: \mathrm{B}\{\mathrm{z}\}+2 * \mathrm{~B} 2 \mathrm{xy}\{\mathrm{z}\}\right)
$$

Table 2. Characteristics of occupied positions in possible phase structures corresponding to compounds

\begin{tabular}{|c|c|}
\hline S.g. (z) & $\mathrm{Ni}_{2} \mathrm{P}$ \\
\hline$P \quad 62 m(3)$ & $\begin{array}{l}6 \mathrm{Ni}:(3(\mathrm{f})+3(\mathrm{~g})) \mathrm{m} 3 \mathrm{~m} \\
3 \mathrm{P}: 1(\mathrm{~b}) \quad 62 \mathrm{~m}+2(\mathrm{c}) \frac{6}{6}\end{array}$ \\
\hline$P \quad 6(3)$ & 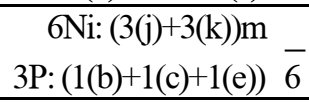 \\
\hline P321 (3) & $\begin{array}{l}\text { 6Ni: (3(e)+3(f))2 } \\
\text { 3P: } 1(\mathrm{~b}) 32+2(\mathrm{~d}) 3\end{array}$ \\
\hline P31m (3) & $\begin{array}{c}\text { 6Ni: } 2 * 3(\mathrm{c}) \mathrm{m} \\
3 \mathrm{P}: 1(\mathrm{a}) 3 \mathrm{~m}+2(\mathrm{~b}) 3\end{array}$ \\
\hline Pmm2 (8) & $\begin{array}{c}\text { 6Ni: } 2 * 8(\mathrm{c}) \mathrm{m} \\
3 \mathrm{P}:(4(\mathrm{a})+4(\mathrm{~b})) \mathrm{mm} 2\end{array}$ \\
\hline P3 (4) & $\begin{array}{c}\text { 8Ni:1(a)3+1(b)3+2*3(d)1 } \\
4 \mathrm{P:} 1(\mathrm{a}) 3+3(\mathrm{~d}) 1 \\
\end{array}$ \\
\hline $\mathrm{Bm}(8)$ & $\begin{array}{c}\text { 6Ni: } 3 * 4(b) 1 \\
3 \mathrm{P}: 2(a) m+4(b) 1\end{array}$ \\
\hline
\end{tabular}
$\mathrm{Ni}_{2} \mathrm{P}$. 
Table 3. Characteristics of occupied positions in possible phase structures corresponding to compounds $\mathrm{Ni}_{3} \mathrm{P}$ and $\mathrm{Ni}_{12} \mathrm{P} 5$.

\begin{tabular}{|c|c|c|c|}
\hline S.g. (z) & $\mathrm{Ni}_{3} \mathrm{P}$ & S.g. (z) & $\mathrm{Ni}_{12} \mathrm{P}_{5}$ \\
\hline $\mathrm{I} 4 / \mathrm{m}(8)$ & - & I 4/m (2) & $\begin{array}{l}\text { 24Ni: } 8 \text { (h) } m+16 \text { (i) } 1 \\
\text { 10P: } 2 \text { (a) } 4 / m+8 \text { (h) } m\end{array}$ \\
\hline I $\overline{4}(8)$ & $\begin{array}{l}\text { 24Ni: } 3 * 8(\mathrm{~g}) 1 \\
8 \mathrm{P}: 8(\mathrm{~g}) 1\end{array}$ & I $\overline{4}(2)$ & $\begin{array}{l}\text { 24Ni: } 3 * 8(\mathrm{~g}) 1 \\
\text { 10P: } 2 \text { (a) } 4+8(\mathrm{~g}) 1\end{array}$ \\
\hline I4 (8) & - & I 4 (2) & $\begin{array}{l}\text { 24Ni:3*8(c) } 1 \\
\text { 10P: } 2 \text { (a) } 4+8(\mathrm{c}) 1\end{array}$ \\
\hline $\mathrm{B} 2 / \mathrm{m}(8)$ & - & B 2/m (2) & $\begin{array}{l}\text { 24Ni: } 3 * 8(\mathrm{j}) 1 \\
\text { 10P: } 2 \text { (a) } 2 / \mathrm{m}+8(\mathrm{j}) 1\end{array}$ \\
\hline B2 (8) & $\begin{array}{l}\text { 24Ni: } 6 * 4(\mathrm{c}) 1 \\
8 \mathrm{P}: 2 * 4(\mathrm{c}) 1\end{array}$ & B 2 (2) & $\begin{array}{l}\text { 24Ni: } 6 * 4(\mathrm{c}) 1 \\
\text { 10P: } 2 \text { (a) } 2+2 * 4 \text { (c) } 1\end{array}$ \\
\hline
\end{tabular}

It is obvious that such transitions are accompanied only by significant changes in the phosphorus sublattice, while the nickel sublattice undergoes only regular deformation changes (Fig. 1). In each pair, phases with a higher concentration of phosphorus can be formed as a result of phosphorus diffusion from the region of a phase with a lower concentration. An increase in the phosphorus atoms diffusion can be due to the high temperature and pressure gradients formed under mechanical action, under the influence of which it is carried out along a fairly well-branched network of boundaries between phases.

Thus, the aforementioned pairs of phases (Fig. 1) relate to each other as the phases of insertion-subtraction. For the $\mathrm{Ni}-\mathrm{P}$ system, this provides a unique opportunity for the redistribution of phosphorus atoms over phosphorus- containing phases in order to minimize the energy of the material surface. In other Me - P systems (where $\mathrm{Me}-\mathrm{Cr}, \mathrm{Mn}, \mathrm{Fe}, \mathrm{Co}$ ), the sets of structures formed are different and there is no such possibility [6].

The possibility of atoms redistribution over the crystal lattices of phases and the formation of phases with a higher concentration of phosphorus on the material surface can provide the effect of hardening the coating surface, increasing their anticorrosive properties and wear resistance. For MexPy significant changes in the volume of Me atoms, which signify "loosening" of the corresponding binary compounds structures [6], are observed for $\mathrm{MeP}, \mathrm{MeP}_{2}$ and $\mathrm{MeP}_{3}$. For other compositions with a relatively low phosphorus content, including $\mathrm{Ni}_{5} \mathrm{P}_{2}, \mathrm{Ni}_{12} \mathrm{P}_{5}$ and $\mathrm{Ni}_{2} \mathrm{P}$, the same packing density of metal atoms is characteristic as in the corresponding simple substance (Fig. 2). The same compounds are characterized by relatively high values of the maximum temperature of stability (Fig. 2).

Thus, the considered possibility of phase and structural-phase disordering in the surface layers of a nickel-phosphorus coating under tribomechanical action is probably the realization of the self-organization process and the adaptability effect of materials that operate under substantially nonequilibrium conditions and function at the required level of their properties manifestation. 


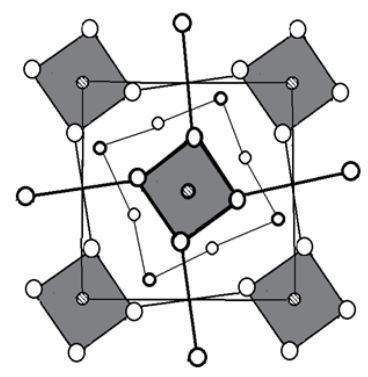

a)

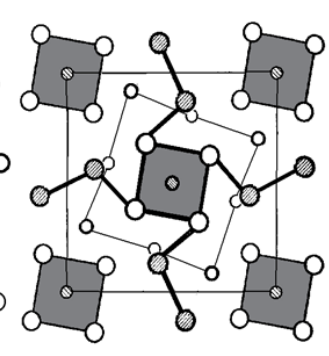

b)
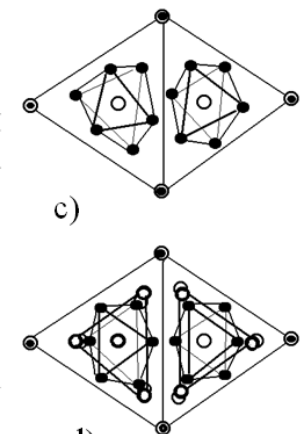

d)

Fig. 1. Idealized images of the projections of the structures of tetragonal I $\overline{4}$ - phases $\mathrm{Ni}_{3} \mathrm{P}(\mathrm{a})$ and $\mathrm{Ni}_{12} \mathrm{P}_{5}$ (b) and trigonal $\mathrm{P} 3$ - phases $\mathrm{Ni}_{5} \mathrm{P}_{2}(\mathrm{c})$ and $\mathrm{Ni}_{5} \mathrm{P}_{4}(\mathrm{~d})$.

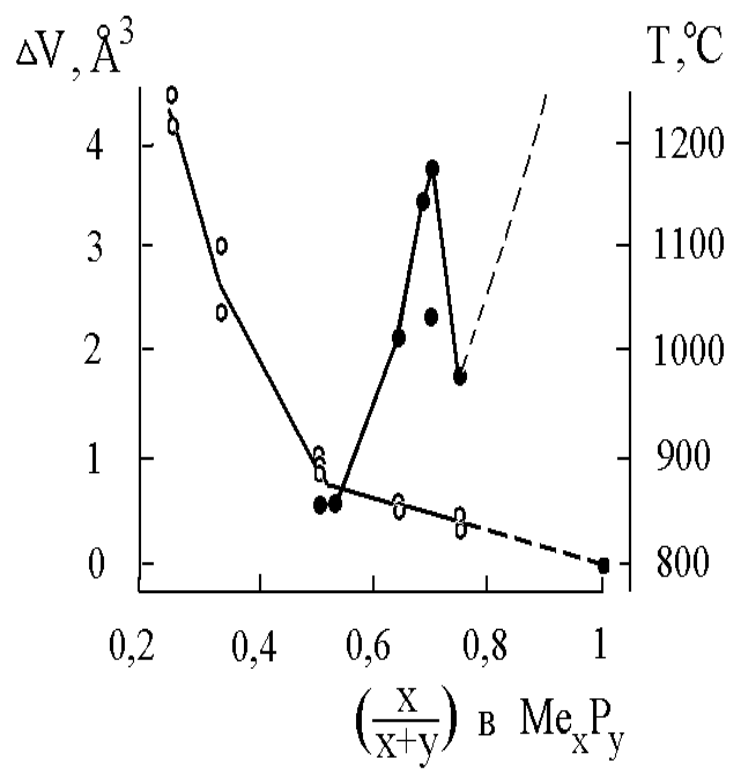

Fig. 2. Me atoms volume changing in phosphorus- containing compounds $\mathrm{MexPy}(\mathrm{Me}-\mathrm{Fe}, \mathrm{Cr}, \mathrm{Ni})$ (light points) and the maximum temperature of NixPy stability depending on the composition.

\section{Conclusion}

The above theoretical studies have shown that at increased contact pressures and temperatures that occur at real points of contact in the tribological contact of friction pairs nickel- phosphorus coating - metal, the Ni-P system has a unique ability to redistribute phosphorus atoms in order to minimize material surface energy. In the process of system self-organization, sets of phases are likely to form, providing nickel-phosphorus coating wear resistance. 


\section{References}

1. A.A. Kutkov, Wear-resistant and anti-friction coatings, M: Mashinostroenie Publ. [Mechanical Engineering Publ.], (1976).

2. I.N. Shcherbakov, V.V. Ivanov, A.A. Korotkiy, Elaboration and Investigation of Metallic Coating with Inclusion of Potassium Polytitanate, Solid State Phenomena, vol. 284, pp. 1140-1143, (2018).

3. I.N. Shcherbakov, A.A. Korotkiy, E.V. Egelskaya, Formation and Properties of Multilayer Composite Solid Lubricant Coating, (ICIE 2019), Lecture Notes in Mechanical Engineering. Springer, Cham. pp 1279-1285.

4. I.N. Shcherbakov, Ivanov V.V., Logvinov V.T., Derlugyan P.D., Trofimov G.E., Derlugyan F.P, Chemical nanoconstruction of composite materials and coatings with antifriction properties, South.-Rus. State Tech. University (NPI). - Rostov-on-Don: Izv. vuzov Sev.Kavk. Region Publ.; Lik Publ., (2011).

5. V.V. Ivanov, I.N. Shcherbakov, Modeling of composite nickel-phosphorus coatings with antifriction properties, South-Russian State Technical University (NPI), Rostov-on-Don: Izv. vuzov Sev.-Kavk. Region Publ., (2008).

6. I.N. Shcherbakov, Development of a composite nickel-phosphorus coating modified with boron nitride and polytetrafluoroethylene: Diss. of cand. tech. sciences. Novocherkassk, (2003).

7. Ivanov V.V. Combinatorial modeling of probable structures of inorganic substances. Rostov-on-Don: SKNTs VSh Publ., (2003).

8. A.A. Kutkov, V.A. Schegolev Structural-kinematic modeling of mobile molecular forms, Rostov-on-Don: Rostov University Publ., (1984). 